International Research Journal of Management, IT \& Social Sciences
Available online at https://sloap.org/journals/index.php/irjmis/
Vol. 8 No. 1, January 2021, pages: 123-131
ISSN: 2395-7492
https://doi.org/10.21744/irjmis.v8n1.1175

\title{
Effect of Instagram and Celebrity Endorser on Purchasing Motive of Le Minerale Packaging Water With Image Brand as Intervention Variables
}

\begin{tabular}{|c|c|}
\hline & $\begin{array}{r}\text { Utari Meitridasari } \\
\text { Zakaria Wahab } \\
\text { Isnurhadi } \\
\text { Marlina Widiyanti }\end{array}$ \\
\hline Article history: & Abstract \\
\hline $\begin{array}{l}\text { Submitted: } 09 \text { November } 2020 \\
\text { Revised: } 27 \text { December } 2020 \\
\text { Accepted: } 18 \text { January } 2021 \\
\text { Keywords: } \\
\text { brand image; } \\
\text { buying interest; } \\
\text { celebrity endorser; } \\
\text { Instagram; } \\
\text { le minerale; }\end{array}$ & $\begin{array}{l}\text { This study aimed to analyze the effect of online marketing methods through } \\
\text { Instagram and celebrity endorsers mediated by the brand image on purchase } \\
\text { interest consumers of bottled drinking water under the Le Minerale brand } \\
\text { produced by PT. Tirta Fresindo Jaya (Mayora Group). The data used are } \\
\text { obtained from questionnaires given to respondents who have never been } \\
\text { consuming a brand product. The collected data then analyzed using multiple } \\
\text { linear regression with SPSS version } 26 \text { software. The results revealed that } \\
\text { Instagram has a positive influence on Le Minerale's brand image. However, } \\
\text { celebrity endorser does not show a positive influence on mineral water. } \\
\text { Through the brand image, Instagram can have a positive influence on } \\
\text { consumer buying interest, while the positive influence of celebrity endorser } \\
\text { has made consumer purchase is more fantastic directly than currently mediated } \\
\text { by brand image. }\end{array}$ \\
\hline & $\begin{array}{r}\text { International research journal of management, IT and social sciences } \odot 2021 . \\
\text { This is an open access article under the CC BY-NC-ND license } \\
\text { (https://creativecommons.org/licenses/by-nc-nd/4.0/). }\end{array}$ \\
\hline $\begin{array}{l}\text { Corresponding author: } \\
\text { Utari Meitridasari, } \\
\text { Sriwijaya University, South Suı } \\
\text { Email address: utarimeitridasa }\end{array}$ & lonesia. \\
\hline
\end{tabular}

Sriwijaya University, South Sumatra, Indonesia

Sriwijaya University, South Sumatra, Indonesia

Sriwijaya University, South Sumatra, Indonesia

Sriwijaya University, South Sumatra, Indonesia 


\section{Introduction}

According to Haug \& Assael (2001), buying interest is a consumer tendency to buy a brand or take action on order, as calculated by buyers' chance of purchasing. (Macdonald \& Sharp, 2000; Ragulina et al., 2017; Tran et al., 2017). Customers with buying interest can be impacted by two variables environmental and marketing stimuli. Environmental factors influence consumer buying interest selection of a particular product, while the marketing stimulus factor seeks to stimulate consumers to attract consumer buying interest. According to Semanjski \& Gautama (2019), social media is one of the online marketing techniques much favored by internet marketers because of its cheap and promotional costs if done manually; it can be said that there is no cost. Instagram is one of the most widely used social media platforms today (Toffler, 1970; Toffler, 1980). After successfully being an application in demand by many users, Instagram has become a social media that has many business opportunities because it can be used as a medium of marketing communications through photo sharing. Boyle et al., (2003), calculated buyers' chance to buy the product, buy a brand, or take any action on a request. Independent quantities may affect customers with purchase desires. From several studies that have been done, celebrity endorsers are influential in shaping a product's brand image, and both become variables (Boyland et al., 2013; Dwivedi \& Johnson, 2013; Ifeanyichukwu, 2016).

\section{Materials and Methods}

The scope discussed is two independent variables, namely Instagram $\left(\mathrm{X}_{1}\right)$ and Celebrity Endorser $\left(\mathrm{X}_{2}\right)$, the intervening variable Brand Image (Z), and the dependent variable of Purchase Interest (Y) for the Le Minerale brand (Creswell \& Creswell, 2017; McCusker \& Gunaydin, 2015; Östlund et al., 2011). The population is potential consumers who have never consumed this product, with an age range of 18-40 years, and have an Instagram account. The sample to be used is 100 respondents. The weighting of the answers to the questionnaire used a five (5) point Likert scale. Meanwhile, each item's weight value is 1 to 5 , according to the alternative answers chosen from each statement/statement. The five weighted score assessments are as follows options:
a) Strongly Disagree : Score of 1
b) Disagree : Score of 2
c) Disagree : Score of 3
d) Agree : Score of 4
e) Strongly Agree : Score of 5

The greater the number of values given by the respondent for each factor shows that these factors are increasingly having a positive effect on purchasing decisions. To calculate upwards of one predictor factor (outcome variable) to the predictor variables is essential, a multiple linear regression was used. The regression formula can be expressed as follow, depending mostly on variables to be researched:

$$
\begin{gathered}
\mathrm{Z}=\mathrm{a}+\mathrm{b}_{1} \mathrm{X}_{1}+\mathrm{b}_{2} \mathrm{X}_{2}+\mathrm{e} \\
\mathrm{Y}=\mathrm{a}+\mathrm{b}_{1} \mathrm{X}_{1}+\mathrm{b}_{2} \mathrm{X}_{2}+\mathrm{b}_{3} \mathrm{Z}+\mathrm{e}
\end{gathered}
$$

\section{Results and Discussions}

Validity test results

Table 1

Results of the research instrument variable validity test

\begin{tabular}{lllll}
\hline Indicator & Point & r-hitung & r-tabel & Description \\
\hline Instagram $\left(\mathrm{X}_{1}\right)$ & 1 & 0,845 & 0,514 & Rational \\
& 2 & 0,883 & 0,514 & Rational \\
& 3 & 0,832 & 0,514 & Rational \\
\hline
\end{tabular}




\begin{tabular}{lllll}
\hline \multirow{3}{*}{ Celebrity Endorser $\left(\mathrm{X}_{2}\right)$} & 4 & 0,707 & 0,514 & Rational \\
& 1 & 0,898 & 0,514 & Rational \\
& 2 & 0,823 & 0,514 & Rational \\
& 3 & 0,850 & 0,514 & Rational \\
& 4 & 0,808 & 0,514 & Rational \\
& 5 & 0,665 & 0,514 & Rational \\
Brand Image (Z) & 6 & 0,605 & 0,514 & Rational \\
& 7 & 0,847 & 0,514 & Rational \\
& 8 & 0,883 & 0,514 & Rational \\
Minat Beli (Y) & 1 & 0,714 & 0,514 & rational \\
& 2 & 0,683 & 0,514 & Rational \\
& 3 & 0,761 & 0,514 & Rational \\
& 4 & 0,809 & 0,514 & Rational \\
& 1 & 0,830 & 0,514 & Rational \\
& 2 & 0,948 & 0,514 & rational \\
& 3 & 0,948 & 0,514 & Rational \\
& 4 & 0,951 & 0,514 & Rational \\
\hline
\end{tabular}

Data Sources: From the survey, 2020

It is established in Table 1 which each variable (item) for each autonomous Instagram and Brand Personality factor, the accompanying Brand Identity variables, and also the contingent Purchasing Interest variable, factors in $\mathrm{r}$-count larger than r-table 0.514 so that the indicator (items) used for this testing variable could be declared valid which can be used as data collection items.

Testing results for reliability

Table 2

Tests of the factor reliability analysis for research instruments

\begin{tabular}{lccccc}
\hline Indicator & $\begin{array}{c}\text { Cronbach's } \\
\text { Alpha }\end{array}$ & Cutt Off & $\begin{array}{c}\mathrm{N} \text { of } \\
\text { Case }\end{array}$ & $\begin{array}{c}\mathrm{N} \text { of } \\
\text { Item }\end{array}$ & Description \\
\hline Instagram $\left(\mathrm{X}_{1}\right)$ & 0,86019 & $>0,60$ & 30 & 5 & Reliable \\
Celebrity Endorser $\left(\mathrm{X}_{2}\right)$ & 0,91353 & $>0,60$ & 30 & 6 & Reliable \\
Brand Image $(\mathrm{Z})$ & 0,73812 & $>0,60$ & 30 & 5 & Reliable \\
Buying Interest $(\mathrm{Y})$ & 0,94219 & $>0,60$ & 30 & 10 & Reliable \\
\hline
\end{tabular}

Data Source: The Survey, 2020

Table 2 each predictor (item) in each exponential function is understood to also be Instagram and Celebrity Endorser, intervening variables Brand Image, as well as the dependent variable Purchase Interest, have Cronbach's Alpha results above 0.60. Based on these results, it can be concluded that the research instrument reliable.

Meitridasari, U., Wahab, Z., Isnurhadi, I., \& Widiyanti, M. (2021). Effect of instagram and celebrity endorser on purchasing motive of le minerale packaging water with image brand as intervention variables. International Research Journal of Management, IT and Social Sciences, 8(1), 123-131. https://doi.org/10.21744/irjmis.v8n1.1175 
Normality test results

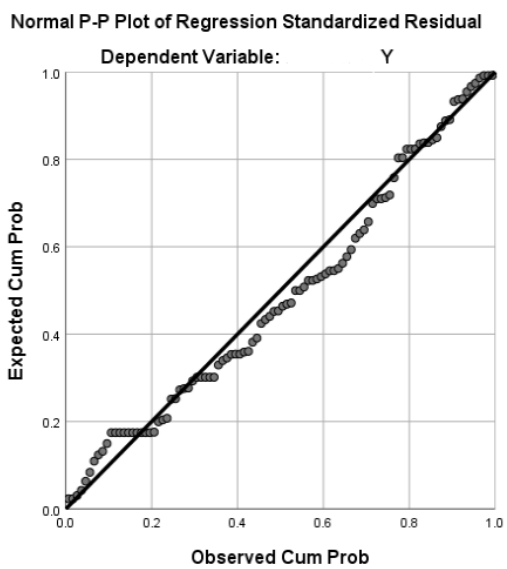

Figure 1. Graphic results of the Research Instrument Variable Normality Test

Data Source: Processed from the Questionnaire, 2020

By looking at the Normal Probability plot display in graph one above, he can conclude that the dots are seen spreading around the diagonal line, as well as the direction the spread follows the diagonal line. The graph expected probability plots show that the data used to meet the assumptions of normality and is feasible to use.

Multicollinearity test results

Table 3

Results of the research instrument variable multicollinearity test

\begin{tabular}{llrrrrrrrr}
\hline & & \multicolumn{3}{c}{ Coefficients $^{\mathbf{a}}$} \\
\hline Model & & \multicolumn{3}{c}{$\begin{array}{c}\text { Standardized } \\
\text { Coefficients } \\
\text { Beta }\end{array}$} & t & Sig. $\begin{array}{c}\text { Collinearity } \\
\text { Statistics } \\
\text { Tolerance }\end{array}$ & VIF \\
\hline 1 & (Constant) & $-3,956$ & 2,930 & & & $-1,350$ & 0,180 & & \\
& Instagram & 0,407 & 0,155 & 0,306 & 2,618 & 0,010 & 0,337 & 2,970 \\
& Celebrity Endorser & 0,322 & 0,092 & 0,373 & 3,491 & 0,001 & 0,402 & 2,487 \\
& Brand Image & 0,296 & 0,169 & 0,156 & 1,748 & 0,084 & 0,578 & 1,729 \\
\hline
\end{tabular}

Data Source: the Survey, 2020

Based on the results of figure 3, multicollinearity among predictor factors doesn't exist since it shows that the VIF value is much less than 10 . 
Report Results for Heteroscedasticity

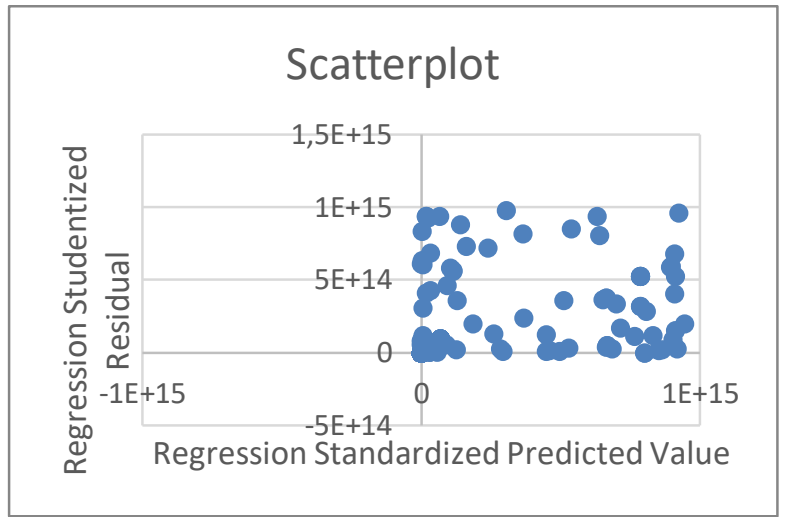

Figure 2. Results of the heteroscedasticity factor for able to collect and analyze

Data Source: Questionnaire, 2020

By looking at the display of the Scatter Plot graph in graph two above, it can see the dots the data a precision measuring also isn't generated by distribution centers. It was thus assumed that perhaps the study data have are heteroscedasticityfree.

Multiple Linear Analysis Results

Table 4

Multiple linear regression analysis test results in $\mathrm{X} 1$ and $\mathrm{X} 2$ against $\mathrm{Z}$

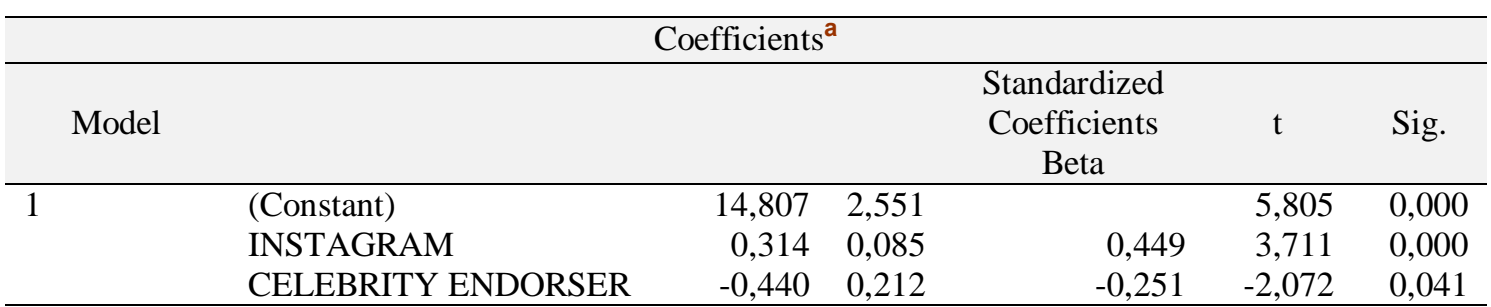

Dependent Variable: BRAND IMAGE

Data Source: Questionnaire, 2020

Based on the results of the very first linear regression line (Table 4) above, it can be seen that the positive calculated term of 14.807 indicates that the alternative hypothesis Instagram $\left(\mathrm{X}_{1}\right)$ has a good impact of 0.314 , while the predictor variables Celebrity Supporter $\left(\mathrm{X}_{2}\right)$ does have a positive influence of -0.440 relative to -0.440 . Brand Logo Interfering Vector (Z).

Table 5

Multiple linear regression analysis test results in $\mathrm{X}_{1}, \mathrm{X}_{2}$, and $\mathrm{Z}$ against $\mathrm{Y}$

\begin{tabular}{|c|c|c|c|c|c|c|}
\hline \multicolumn{7}{|c|}{ Coefficients } \\
\hline Model & & & & $\begin{array}{c}\text { Standardized } \\
\text { Coefficients } \\
\text { Beta }\end{array}$ & $\mathrm{t}$ & Sig. \\
\hline 1 & (Constant) & 3,830 & 1,207 & & 3,173 & 0,002 \\
\hline & INSTAGRAM & $-0,110$ & 0,039 & $-0,295$ & $-2,789$ & 0,006 \\
\hline & CELEBRITY ENDORSER & 0,282 & 0,098 & 0,303 & 2,895 & 0,005 \\
\hline & BRAND IMAGE & 0,380 & 0,114 & 0,284 & 3,328 & 0,001 \\
\hline
\end{tabular}

Dependent Variable: BUY INTEREST

Data Source: Questionnaire, 2020

Meitridasari, U., Wahab, Z., Isnurhadi, I., \& Widiyanti, M. (2021). Effect of instagram and celebrity endorser on purchasing motive of le minerale packaging water with image brand as intervention variables. International Research Journal of Management, IT and Social Sciences, 8(1), 123-131. https://doi.org/10.21744/irjmis.v8n1.1175 
Based on the results of the first linear regression line (Table 4) below, it can be seen that the positive calculated term of 14.807 shows a positive impact of 0.314 between both the variable Instagram $\left(\mathrm{X}_{1}\right)$, a point up of -0.440 between both the variable Celebrity Endorser $\left(\mathrm{X}_{2}\right)$ and -0.314 between the independent variable brand Identity $\left(\mathrm{X}_{1}\right)(\mathrm{Z})$.

Model Feasibility Test Results (F Test)

Table 6

Feasibility Test Results for Models F X1 and X2 against Z

\begin{tabular}{|c|c|c|c|c|c|c|}
\hline \multicolumn{7}{|c|}{$\mathrm{ANOVA}^{\mathrm{a}}$} \\
\hline \multicolumn{2}{|c|}{ Model } & $\begin{array}{l}\text { Sum of } \\
\text { Squares }\end{array}$ & df & $\begin{array}{l}\text { Mean } \\
\text { Square }\end{array}$ & $\mathrm{F}$ & Sig. \\
\hline 1 & Regression & 195,629 & 2 & 97,814 & 38,061 & $.000^{b}$ \\
\hline & Residual & 249,281 & 97 & 2,570 & & \\
\hline & Total & 444,910 & 99 & & & \\
\hline
\end{tabular}

Dependent Variable: BRAND IMAGE

Predictors: (Constant), CELEBRITY ENDORSER, INSTAGRAM

Data Source: Questionnaire, 2020

That calculated value, based on table 6, is 38.061 with such a level of significance of 0.000 . Therefore, the F-number 38.061 meaning is more basic $\mathrm{F}$ table $(\mathrm{dF}=3: 96)=3.99$ and sig. $\mathrm{F} 0.000$, implying less than 0.05 , so the $\mathrm{H} 1$ hypothesis is acknowledged, and Ho is rejected. The variable used in the linear regression, respectively Instagram $\left(\mathrm{X}_{1}\right)$ or Brand Personality $\left(\mathrm{X}_{2}\right) \mathrm{s}$, can infer that.

Table 7

Feasibility Test Results for Models F X1, X2, and Z against Y

\begin{tabular}{llrrrrr}
\hline \multicolumn{7}{c}{ ANOVA $^{\mathrm{a}}$} \\
\hline \multirow{2}{*}{ Model } & Sum of & \multicolumn{1}{c}{ Mean } & & \\
& & Squares & df & Square & F & Sig. \\
\hline 1 & Regression & 77,034 & 3 & 25,678 & 51,115 & $.000^{\mathrm{b}}$ \\
& Residual & 48,227 & 96 & 0,502 & & \\
& Total & 125,261 & 99 & & & \\
\hline Dependent Variable: BRAND IMAGE \\
Predictors: (Constant), CELEBRITY ENDORSER, INSTAGRAM \\
Data Source: Questionnaire, 2020 \\
Predictors: (Constant), BRAND IMAGE, CELEBRITY ENDORSER, \\
INSTAGRAM
\end{tabular}

Based on table 7 , the calculated $F$ value is 51,115 with a significance level of 0,000 . Thus the value of $F$ count 51,115 is more basic $\mathrm{F}$ table $(\mathrm{dF}=3: 96)=3.99$ and sig. $\mathrm{F} 0,000$, which means less than 0.05 , so the hypothesis $\mathrm{H} 1$ is accepted and Ho is rejected. The independent variables used in the regression model, namely Instagram, may thus be inferred $\left(X_{1}\right)$ and Celebrity Endorser $\left(X_{2}\right)$, as well as the intervening variable Brand Image $(Z)$, simultaneously (together) affect the dependent variable Purchase of interest (Y) bottled drinking water Le Minerale in Palembang City (Cretu \& Brodie, 2007; Wu et al., 2011).

It can be represented based on the results of the t-test study results in Tables 8 and 9 .

Just as follows:

1) The study of the brand picture $(Z)$ effect of Instagram $\left(X_{1}\right)$ has a beta value of 0.314 with a substantial value of 0.000 lower than 0.05 . This suggests that there is a positive and vital impact of the Instagram variable on the brand profile.

2) The celebrity endorser $\left(X_{2}\right)$ effect on the brand profile $(Z)$ study has a beta value of -0.440 with a significance value of 0.041 , which is less than 0.05 . This suggests that celebrities' sponsorship has a negative and vital influence on the reputation of the brand. 
3) Instagram's $\left(\mathrm{X}_{1}\right)$ impact on buying decision $(\mathrm{Y})$ evaluation has a beta impact of -0.119 with a critical value of 0.006 , which would be lower than 3. A. 0.05 . This means there is a negative and significant impact of the Instagram variable on purchasing interest.

4) The effects on purchasing interest $(\mathrm{Y})$ of the celebrity endorser $(\mathrm{X} 2)$ study has a beta effect of 0.282 with a significance value of 0.005 smaller than 0.05 . This suggests that factors helping celebrities have a positive and powerful impact on the purpose of buying.

5) Examining the effect of the brand name $(\mathrm{Z})$ on the decision to buy $(\mathrm{Y})$ is right; the beta impact is 0.380 with a significance value of 0.001 below 0.05 . This suggests that the brand value predictor has a vital and robust influence on the purpose of buying.

Recapitulation of Research Results

Table 8

Recapitulation of research results

\begin{tabular}{|c|c|}
\hline Hypothesis & Research Results \\
\hline H0: Instagram towards brand image rejected & H1: Instagram has a positive effect and significant \\
\hline Ha: Instagram on the brand image be accepted & to the brand image \\
\hline H0: Celebrity endorser of brands image rejected & $\mathrm{H} 2$ : An influential celebrity endorser negative and \\
\hline Ha: Celebrity endorser toward brand image accept & significant to the brand image \\
\hline H0: Instagram on buying interest rejected & H3: Instagram has a negative effect and significant \\
\hline Ha: Instagram on buying interest dit accept & to purchase interest \\
\hline $\begin{aligned} & \mathrm{H} 0: \text { Brand image mediates Instagram and celebrity } \\
& \text { endorsers against buying interest is rejected }\end{aligned}$ & $\begin{array}{l}\text { H4: Influential celebrity endorser positive and } \\
\text { significant towards interest buy }\end{array}$ \\
\hline Ha: Celebrity endorser towards interests buy accepted & \\
\hline $\begin{array}{l}\mathrm{H} 0: \text { Brand image mediates Instagram and celebrity } \\
\text { endorsers against buying interest is rejected }\end{array}$ & $\begin{array}{l}\text { H5: Instagram and celebrity endorser through } \\
\text { an influential brand image positive and }\end{array}$ \\
\hline $\begin{array}{l}\text { Ha: Brand image mediates Instagram and celebrity } \\
\text { endorser on interests buy accepted }\end{array}$ & significant towards interest buy \\
\hline
\end{tabular}

Data Source: Processed from the Questionnaire, 2020

\section{Implication}

It is predicted that this research's theoretical results would be useful for the creation of theoretical knowledge related to buying interest, which can be seen from the marketing method, which has a significant effect on buying interest in bottled drinking water products Le Mineral. There are many functional consequences for the affiliated companies, including the marketing department of Le Minerale, based on the results of the research that has been done, and more investigators are expected to use this analysis as an alternative to choose which variable is better used, based as to what is seen from related parties and further investigators towards evaluation criteria.

\section{Conclusion}

a) The positive and significant impact of Instagram on the image of the Le Minerale product is celebrity endorsers hurt Le Minerale's brand image Instagram hurts consumer buying interest in drinking water Le Minerale packaging in Palembang City.

b) Celebrity endorsers have a positive and significant effect on purchase intention consumers of Le Minerale bottled drinking water in Palembang City.

c) In mediating the impact of Instagram and celebrity supporters on customers purchasing an interest in drinking water, Le Minerale packaging in Palembang City has a positive and important effect on brand recognition.

Meitridasari, U., Wahab, Z., Isnurhadi, I., \& Widiyanti, M. (2021). Effect of instagram and celebrity endorser on purchasing motive of le minerale packaging water with image brand as intervention variables. International Research Journal of Management, IT and Social Sciences, 8(1), 123-131. https://doi.org/10.21744/irjmis.v8n1.1175 
Conflict of interest statement

The authors declared that they have no competing interests.

Statement of authorship

The authors have a responsibility for the conception and design of the study. The authors have approved the final article.

\section{Acknowledgments}

We thank many parties who volunteered to accompany this work during the writing period to complete this paper as planned. We carry out this research as part of our duties and obligations as part of our author's academic completeness. We are grateful to two anonymous reviewers and editors who have cooperatively support this project entitled "The Effect Of Instagram and Celebrity Endorser on The Purchasing Motive of Le Minerale Packaging Water With The Image Brand As Intervention Variables" 


\section{References}

Boyland, E. J., Harrold, J. A., Dovey, T. M., Allison, M., Dobson, S., Jacobs, M. C., \& Halford, J. C. (2013). Food choice and overconsumption: effect of a premium sports celebrity endorser. The Journal of pediatrics, 163(2), 339343. https://doi.org/10.1016/j.jpeds.2013.01.059

Boyle, J. W., Shimp, L. A., Kaes, D. R., Morris, J. W., Martz, E. O., Boyce, T. M., \& Daugherty, M. (2003). Rampshaped intervertebral implant. Google Patents.

Creswell, J. W., \& Creswell, J. D. (2017). Research design: Qualitative, quantitative, and mixed methods approaches. Sage publications.

Cretu, A. E., \& Brodie, R. J. (2007). The influence of brand image and company reputation where manufacturers market to small firms: A customer value perspective. Industrial marketing management, 36(2), $230-240$. https://doi.org/10.1016/j.indmarman.2005.08.013

Dwivedi, A., \& Johnson, L. W. (2013). Trust-commitment as a mediator of the celebrity endorser-brand equity relationship in a service context. Australasian Marketing Journal (AMJ), 21(1), 36-42. https://doi.org/10.1016/j.ausmj.2012.10.001

Haug, R. H., \& Assael, L. A. (2001). Outcomes of open versus closed treatment of mandibular subcondylar fractures. Journal of oral and maxillofacial surgery, 59(4), 370-375. https://doi.org/10.1053/joms.2001.21868

Ifeanyichukwu, C. D. (2016). Effect of celebrity endorsements on consumers purchase decision in Nigeria. International research journal of management, IT and social sciences, 3(9), 120-128.

Macdonald, E. K., \& Sharp, B. M. (2000). Brand awareness effects on consumer decision making for a common, repeat purchase product: A replication. Journal of business research, 48(1), 5-15. https://doi.org/10.1016/S01482963(98)00070-8

McCusker, K., \& Gunaydin, S. (2015). Research using qualitative, quantitative or mixed methods and choice based on the research. Perfusion, 30(7), 537-542.

Östlund, U., Kidd, L., Wengström, Y., \& Rowa-Dewar, N. (2011). Combining qualitative and quantitative research within mixed method research designs: a methodological review. International journal of nursing studies, 48(3), 369-383. https://doi.org/10.1016/j.ijnurstu.2010.10.005

Ragulina, Y. V., Semenova, E. I., Avkopashvili, P. T., Dmitrieva, E. A., \& Cherepukhin, T. Y. (2017, December). Top-priority directions of implementing new internet technologies on the territories of rapid economic development. In Perspectives on the use of New Information and Communication Technology (ICT) in the Modern Economy (pp. 182-188). Springer, Cham.

Semanjski, I., \& Gautama, S. (2019). A collaborative stakeholder decision-Making approach for sustainable urban logistics. Sustainability, 11(1), 234.

Toffler, A. (1970). Future shock. Bantam.

Toffler, A. (1980). The Third Wave. William Morrow and Company. Inc., New York.

Tran, H., Abbott, M., \& Yap, C. J. (2017). How does working capital management affect the profitability of Vietnamese small-and medium-sized enterprises?. Journal of Small Business and Enterprise Development.

Wu, P. C., Yeh, G. Y. Y., \& Hsiao, C. R. (2011). The effect of store image and service quality on brand image and purchase intention for private label brands. Australasian Marketing Journal (AMJ), 19(1), 30-39. https://doi.org/10.1016/j.ausmj.2010.11.001

Meitridasari, U., Wahab, Z., Isnurhadi, I., \& Widiyanti, M. (2021). Effect of instagram and celebrity endorser on purchasing motive of le minerale packaging water with image brand as intervention variables. International Research Journal of Management, IT and Social Sciences, 8(1), 123-131. https://doi.org/10.21744/irjmis.v8n1.1175 